\title{
Zakres badań naukowych w pielęgniarstwie rodzinnym. Przegląd piśmiennictwa z lat 1995-2015
}

\section{The scope of scientific research in family nursing. Review of literature from 1995-2015}

\author{
Ewa Taranta ${ }^{\circledR}$, Ludmiła Marcinowicz¹, Barbara Ślusarska² \\ ${ }^{1}$ Uniwersytet Medyczny w Białymstoku, Zakład Podstawowej Opieki Zdrowotnej, ul. Mieszka I 4B, 15-054 Białystok \\ Medical University of Bialystok, Department of Primary Health Care \\ ${ }^{2}$ Uniwersytet Medyczny w Lublinie, Zakład Medycyny Rodzinnej i Pielęgniarstwa Środowiskowego, ul. Staszica 4-6, 20-081 Lublin \\ Medical University of Lublin, Department of Family Medicine and Community Nursing, Chair of Oncology and Environmental Health \\ $\bowtie$ ewa.taranta@umb.edu.pl
}

\begin{abstract}
Introduction: Family nursing is a developing specialty in nursing that is undergoing a rapid transformation due to reforms in primary health care in Poland implemented in 1995. The wide autonomy of family nurses in providing health services requires their lifelong learning as well as applying scientific findings in their regular practices.

The objective of the following paper was to summarize empirical research into family nursing conducted in Poland from 1995-2015. Materials and methods: The method of critical analysis of published literature was applied. The Polish Medical Bibliography, PubMed database and Google Scholar search engine were used as a base for data collection. Literature collection was limited to articles published between 1995-2015 concerning services performed by family nurses in Poland.
\end{abstract}

Results: It was established that over the 21 year period the highest number of empirical papers were published between 2010-2015. The vast majority of them were quantitative research studies using a questionnaire technique. The published articles concerned the following research groups: 1) patients - recipients of the services; 2) services providers - family nurses; 3) family doctors and informal carers of people under the care of a family nurse, taking into account the nurse-patient relationship. Conclusions: 1 . There was an evident lack of methodological variety in the reviewed literature. 2 . The role of family nurses in health prevention in children and people of a productive age was marginalized in the analyzed papers. 3. Despite their competences, family nurses perform few independent tasks. Keywords: family nurse; primary health care; health benefits.

\begin{abstract}
ABSTRAKT
Wstęp: Pielęgniarstwo rodzinne jest rozwijającą się specjalizacją pielęgniarską podlegającą szybkim przemianom związanym z zapoczątkowaną w 1995 r. reformą podstawowej opieki zdrowotnej w Polsce. Szeroki zakres samodzielności pielęgniarek rodzinnych w realizacji świadczeń zdrowotnych wymaga od nich ustawicznego kształcenia oraz konieczności wykorzystania w codziennej praktyce wyników badań naukowych.

Celem pracy jest określenie rodzaju i zakresu badań empirycznych w obszarze pielęgniarstwa rodzinnego prowadzonych w Polsce w latach 1995-2015.

Materiały i metody: Zastosowano metodę analizy i krytyki piśmiennictwa. Bazę do wyszukiwania danych stanowiła Polska Bibliografia Lekarska, baza PubMed oraz wyszukiwarka Google Scholar. Poszukiwanie prac było ograniczone do artykułów opublikowanych w latach 1995-2015 i dotyczących świadczeń realizowanych przez pielęgniarki rodzinne w Polsce.
\end{abstract}

Wyniki: Ustalono, że w analizowanych pracach przewagę stanowiły badania ilościowe z wykorzystaniem techniki ankiety. Opublikowane prace mieściły się w następujących grupach badawczych: 1) pacjenci - odbiorcy świadczeń; 2) realizatorzy świadczeń, tj. pielęgniarki rodzinne; 3) lekarze rodzinni oraz opiekunowie nieformalni osób objętych opieką pielęgniarki rodzinnej z uwzględnieniem relacji pielęgniarka-pacjent.

Wnioski: 1. Widoczny jest brak różnorodności metodologicznej $\mathrm{w}$ badaniu roli pielęgniarki rodzinnej. 2 . W pracach zmarginalizowana jest rola pielęgniarki rodzinnej w opiece nad osobami $w$ wieku rozwojowym i produkcyjnym. 3. Pielęgniarki rodzinne wykonują niewiele zadań samodzielnych wynikających z posiadanych kompetencji.

Słowa kluczowe: pielęgniarka rodzinna; opieka podstawowa; świadczenia zdrowotne.

\section{WSTĘP}

Pielęgniarstwo rodzinne jest rozwijającą się specjalizacją pielęgniarską podlegającą szybkim przemianom związanym z zapoczątkowaną w 1995 r. reformą podstawowej opieki zdrowotnej (POZ) w Polsce [1]. Szeroki zakres samodzielności pielęgniarek rodzinnych w realizacji świadczeń zdrowotnych wymaga od nich ustawicznego kształcenia oraz konieczności wykorzystania w codziennej praktyce wyników badań naukowych. W polskiej literaturze pielęgniarskiej funkcjonują takie pojęcia jak „pielęgniarstwo oparte na dowodach naukowych” (evidence-based nursing) czy „praktyka oparta na dowodach 
naukowych" (evidence-based practice) [2]. Rozwój badań pielęgniarskich wymaga jednak odpowiedniej liczby pielęgniarek przygotowanych do prowadzenia badań naukowych, mających czas i możliwości ich realizacji [3]. Można przypuszczać, że to, jaką uwagę przypisują badacze pielęgniarce rodzinnej, będzie przekładać się na jej postrzeganie w społeczeństwie.

Celem pracy było określenie rodzaju i zakresu badań empirycznych w obszarze pielęgniarstwa rodzinnego prowadzonych w Polsce w latach 1995-2015.

\section{MATERIAŁY I METODY}

Zastosowano metodę analizy i krytyki piśmiennictwa. Bazę przedmiotową stanowiła Polska Bibliografia Lekarska (PBL) i anglojęzyczna baza PubMed. Ponadto skorzystano z wyszukiwarki Google Scholar, a także zastosowano tzw. przeszukiwanie ręczne. Strategia poszukiwania prac była ograniczona do artykułów opublikowanych w latach 1995-2015 oraz tych badań, które były przeprowadzone w Polsce.

W PBL, wykorzystując słowa kluczowe: „pielęgniarstwo środowiskowe”, „pielęgniarstwo rodzinne”, „opieka pielęgniarska podstawowa", odnaleziono 288 rekordów, z czego do ostatecznej analizy zakwalifikowano 20 prac. W anglojęzycznej bazie PubMed, stosując hasło: „community nurse” and „Poland”, odnaleziono 45 rekordów, z czego do ostatecznej analizy zakwalifikowano 9 prac. Korzystając z przeglądarki Google Scholar, po zastosowaniu słów kluczowych: „pielęgniarka rodzinna”, ,pielęgniarka podstawowej opieki zdrowotnej”, „podstawowa opieka zdrowotna”, odnaleziono 12 prac, z czego w analizie wykorzystano 6 prac. W wyniku „przeszukiwania ręcznego" innych źródeł do analizy włączono 5 prac związanych z tematem.

\section{Selekcja danych}

Pierwszy autor przeprowadzał selekcję danych na wszystkich włączonych publikacjach. Drugi autor potwierdził ekstrakcję danych w zakresie przyjętych do oceny publikacji. Dane z każdego artykułu zostały uzyskane w przeglądzie przez dwóch niezależnych autorów. Różnice były rozstrzygane po zasięgnięciu opinii trzeciego autora artykułu. W procesie przeglądu wyodrębniono następujące elementy: wielkość próby, okres zbierania danych, narzędzia badawcze, wyniki badania, hipotezy zmienne niezależne, zmienne zależne i skale pomiaru, dokonane analizy oraz uzyskane wnioski mające znaczenie dla przeglądu.

\section{Kryteria włączenia}

Przegląd obejmował badania opublikowane w latach 1995-2015, wg następujących kryteriów: 1) prace oryginalne; 2) badania naukowe prowadzone w Polsce; 3) prace związane z realizacją świadczeń zdrowotnych przez pielęgniarki rodzinne.

\section{Kryteria wyłączenia}

W procesie analizy wykluczone zostały: prace poglądowe, kazuistyczne, podręczniki dotyczące programów kształcenia podyplomowego, zachowań zdrowotnych pacjentów, pielęgniarki

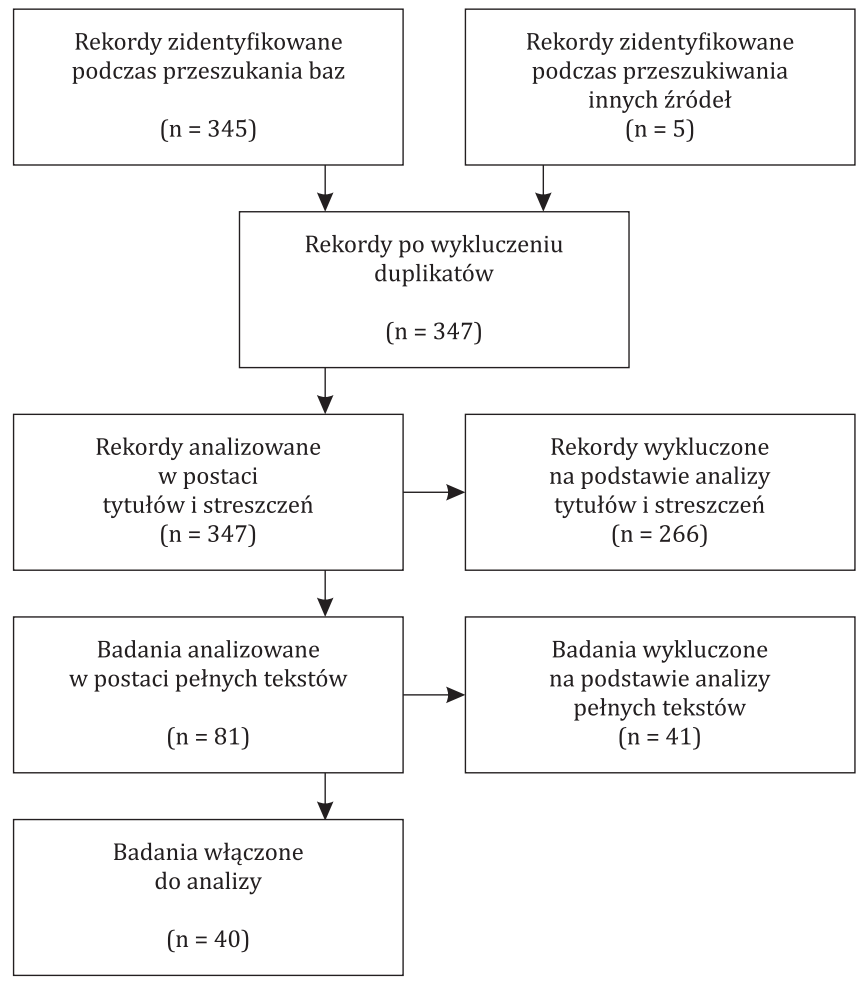

RYCINA 1. Schemat etapów selekcji rekordów według konwencji PRISMA

szkolnej i położnej POZ, sektora opieki społecznej, prace magisterskie/doktorskie, doniesienia zjazdowe, broszury informacyjne, a także badania, które nie były prowadzone w Polsce. Etapy selekcji rekordów wg konwencji PRISMA przedstawiono na rycinie 1 [4].

Ostatecznie przedmiotem analizy objęto 40 prac oryginalnych $[5,6,7,8,9,10,11,12,13,14,15,16,17,18,19,20,21,22,23$, $24,25,26,27,28,29,30,31,32,33,34,35,36,37,38,39,40,41,42$, $43,44]$. Szczegółowo przeanalizowano cele badawcze, metodę i technikę badań oraz główne wyniki. Przeglądu literatury dokonano na przełomie 2016 i 2017 r.

\section{WYNIKI}

Spośród 40 prac oryginalnych opublikowanych na przestrzeni 21 lat 16 (40\%) powstało w latach 2010-2015. Wyniki badań empirycznych dotyczące pielęgniarstwa rodzinnego były publikowane w następujących czasopismach: Problemy Pielęgniarstwa - 5 (12,5\%); Gerontologia Polska - 5 (12,5\%); Problemy Higieny i Epidemiologii - 4 (10\%); Przegląd Lekarski - 3 (7,5\%); Medycyna Ogólna - 3 (7,5\%); Zdrowie Publiczne - 3 (7,5\%); Annales Universitatis Mariae Curie-Skłodowska - 3 (7,5); Family Medicine \& Primary Care - 2 (5\%). Poza tym po jednej pracy $(2,5 \%)$ opublikowano w takich czasopismach, jak: Pielęgniarstwo Polskie, Pielęgniarstwo XXI Wieku, Clinical Interventions in Aging, Polski Przegląd Kardiologiczny, Hygea Public Health, Advances in Medical Sciencies, Roczniki Akademii Medycznej w Białymstoku, Medycyna Pracy, Problemy Medycyny 
TABELA 1. Przegląd badań empirycznych w obszarze pielęgniarstwa rodzinnego w grupie pacjentów - odbiorców świadczeń podstawowej opieki zdrowotnej (POZ) w latach 1995-2015

\begin{tabular}{|c|c|c|c|c|c|}
\hline Lp. & Autorzy & Cel pracy & $\begin{array}{c}\text { Grupa } \\
\text { i liczba } \\
\text { badanych }\end{array}$ & $\begin{array}{l}\text { Metoda / } \\
\text { narzędzie } \\
\text { badawcze }\end{array}$ & Główne wyniki badań \\
\hline 1. & $\begin{array}{l}\text { Oskędra i wsp., } \\
2015 \text { [5] }\end{array}$ & $\begin{array}{l}\text { ocena satysfakcji pacjentów w star- } \\
\text { szym wieku z opieki środowiskowej } \\
\text { świadczonej w ramach podstawowej } \\
\text { opieki zdrowotnej }\end{array}$ & $\begin{array}{l}\text { pacjenci; } \\
\mathrm{n}=100\end{array}$ & $\begin{array}{l}\text { sondaż diagno- } \\
\text { styczny / autor- } \\
\text { ski kwestiona- } \\
\text { riusz ankiety }\end{array}$ & $\begin{array}{l}\text { 1) } 47 \% \text { ankietowanych wysoko ocenia opiekę środo- } \\
\text { wiskową, } \\
\text { 2) o możliwości korzystania z opieki środowiskowej } \\
\text { ankietowani dowiadywali się od pielęgniarek i lekarzy }\end{array}$ \\
\hline
\end{tabular}

3. Leszczyńska poznanie opinii pacjentów na temat pacjenci; i wsp., 2007 [7] świadczeń lekarzy i pielęgniarek śro- n = 1057 dowiskowo-rodzinnych badanie surveyowe / autorski kwestionariusz ankiety
1) $48 \%$ ankietowanych miało kontakt z pielęgniarką rodzinną podczas wizyty w poradni,

2) $95 \%$ badanych oceniło pracę pielęgniarki rodzinnej jako dobrą lub bardzo dobrą,

3) 3/4 respondentów nie korzystało z wizyt pielęgniarek rodzinnych w domu z powodu braku takiej potrzeby

4. Brodzińska i wsp., 2010 [8]

poznanie czynników, jakie determi- pacjenci; nują opinie o jakości opieki pielę- $n=100$ gniarki podstawowej opieki zdrowotnej

autorski kwestionariusz ankiety

1) $54 \%$ badanych korzystających więcej niż $6 \times z$ opieki pielęgniarki POZ oceniło opiekę jako bardzo dobrą, 2) czynnikiem wpływającym na ocenę opieki był czas oczekiwania (67\%), cechy charakteru pielęgniarki uprzejmość, takt (83\%), fachowość (59\%)

5. Piotrowski uzyskanie wiedzy nt. dostępności pacjenci; kwestionariusz i Polakowska, ustug medycznych w opinii pacjen- $n=21600$ ankiety 2010 [9] tów zamieszkujących w gminach matych, średnich, dużych i w miastach wojewódzkich

6. Marcinowicz uzyskanie odpowiedzi na pytania: pacjenci; i wsp., 2004 [10] 1) jaki odsetek starszych pacjentów $n=470$ korzysta z usług domowych lekarza I badanie rodzinnego, a jaki z usług domowych $n=217$ pielęgniarki rodzinnej; 2) czy korzy- II badanie stanie $z$ wizyt domowych lekarskich $n=253$ i pielęgniarskich jest zależne od wieku badanych

7. Doroszkiewicz przedstawienie demograficznie pacjenci i Bień, 2003 [11] uwarunkowanej nierówności w do- powyżej stępie do świadczeń opiekuńczych 75. r.ż.; pielęgniarek środowiskowych oraz $n=230$ określenie zakresu i intensywności domowych wizyt pielęgniarskich w zależności od potencjalnego zapotrzebowania na opiekę

8. Bień, 2002 [12] porównanie opieki zdrowotnej nad pacjenci ludźmi starymi w Polsce w wiejskim powyżej i miejskim środowisku zamieszkania 65. r.ż.;

populacyjne badanie reprezentatywne / 1) $84,04 \%$ kobiet i $83,01 \%$ badanych mężczyzn korzystało $w$ ciągu ostatniego roku z porad udzielanych w POZ,

2) im większa liczebność gminy, tym mniej osób korzystało z usług POZ

kwestionariusz $\quad$ 1) $53,3 \%$ pacjentów powyżej 75 . r.ż. korzystało z wizyt wywiadu domowych pielegniarek rodzinnych w ciagu ostatnich 12 miesięcy w I badaniu, 56,1\% w II badaniu, 2) głównym celem wizyt pielęgniarek u pacjentów powyżej 75 . r.z. były zabiegi lecznicze w $32 \%$ w I badaniu oraz w $51 \%$ w II badaniu

badanie epidemiologiczne /

standaryzowane 2) zaobserwowano większą intensywność wizyt dokwestionariusze mowych lekarza $-53 \%$ badanych w stosunku do wizyt pielęgniarskich $-28 \%$,

3) pielęgniarki zrealizowały 5 i więcej wizyt domowych w ciągu roku u pacjentów obłożnie chorych - 25\% nariuszowy środowiskowej w domu,

3) tylko 1,5\% badanych na wsi i 0,3\% w mieście korzystało z samodzielnych porad pielęgniarskich

9. Borowiak i wsp., analiza porównawcza oczekiwań pacjenci 2015 [13] osób starszych ze środowisk miej- powyżej skich, wiejskich i przebywających 65. r.ż.; w instytucjach opiekuńczych do- $\mathrm{n}=2627$

badanie przekrojowe / kwestionariusz, skale

1) $56,6 \%$ osób badanych ze środowisk miejskich i $54,7 \%$ ze środowisk wiejskich uzyskiwało opiekę przede wszystkim od członków rodziny,

2) $30,3 \%$ respondentów mieszkających samotnie liczyło na opiekę pielęgniarki w odniesion nej z uwzględnieniem elementów całościowej oceny geriatrycznej

10. Wojszel i Bień, ocena wystepowania wielkich pro- pacjenci; $2002[14]$

blemów geriatrycznych u osób po- $n=463$ wyżej 75. r.ż. przekrojowe badanie surveyowe / kwestionariuszowe instrumenty oceny sprawności
1) $17,1 \%$ ankietowanych posiadało ograniczenia sprawności motorycznej,

2) $18,4 \%$ badanych osób w podeszłym wieku pielęgniarka odwiedziła w domu w ciągu ostatnich 12 miesięcy (27,8\% w mieście i 9\% na wsi) 


\begin{tabular}{|c|c|c|c|c|c|}
\hline Lp. & Autorzy & Cel pracy & $\begin{array}{c}\text { Grupa } \\
\text { i liczba } \\
\text { badanych }\end{array}$ & $\begin{array}{l}\text { Metoda / } \\
\text { narzędzie } \\
\text { badawcze }\end{array}$ & Główne wyniki badań \\
\hline 11. & $\begin{array}{l}\text { Kurowska } \\
\text { i Wrońska, } 2005 \\
\text { [15] }\end{array}$ & $\begin{array}{l}\text { zorientowanie się, na ile dokumen- } \\
\text { tacja prowadzona przez pielęgniarki } \\
\text { środowiskowe jest pomocna w za- } \\
\text { spokajaniu potrzeb zdrowotnych ba- } \\
\text { danej populacji }\end{array}$ & $\begin{array}{l}\text { pacjenci; } \\
\mathrm{n}=132\end{array}$ & $\begin{array}{l}\text { wywiady kwe- } \\
\text { stionariuszowe }\end{array}$ & $\begin{array}{l}\text { 1) wśród } 59,1 \% \text { badanych występowała zwiększona } \\
\text { masa ciata, } \\
\text { 2) } 58,3 \% \text { respondentów jako zagrożenie zdrowia } \\
\text { wskazało nadmierne picie kawy, } 56,8 \% \text { nadmierny } \\
\text { stres, } 47,7 \% \text { obniżoną aktywność fizyczną, } \\
\text { 3) } 82 \% \text { badanych nie zdawało sobie sprawy ze znacze- } \\
\text { nia stylu życia dla zdrowia }\end{array}$ \\
\hline 12. & $\begin{array}{l}\text { Szczerbińska } \\
\text { i wsp., } 2011 \text { [16] }\end{array}$ & $\begin{array}{l}\text { ocena skuteczności szkolenia pie- } \\
\text { lęgniarek poprzez pomiar zmiany } \\
\text { aktywności fizycznej i nawyków ży- } \\
\text { wieniowych starszych pacjentów } \\
\text { oraz intencji zmiany tych zachowań } \\
\text { w wyniku oddziaływania pielęgnia- } \\
\text { rek wyposażonych w nowe kompe- } \\
\text { tencje }\end{array}$ & $\begin{array}{l}\text { pacjenci; } \\
\mathrm{n}=108\end{array}$ & $\begin{array}{l}\text { kwestionariusz } \\
\text { wywiadu / } \\
\text { pomiary masy } \\
\text { ciała, wysokości, } \\
\text { obwodu talii, } \\
\text { ocena wartości } \\
\text { wskaźnika masy } \\
\text { ciała }\end{array}$ & $\begin{array}{l}\text { 1) w wyniku interwencji uzyskano wzrost zadowolenia } \\
\text { z aktywności fizycznej z } 27,1 \text { do } 34,4 \% \text {, } \\
\text { 2) szkolenie pielęgniarek skutecznie przełożyło się } \\
\text { na pozytywne zmiany zachowań pacjentów w wieku } \\
60+\end{array}$ \\
\hline 13. & $\begin{array}{l}\text { Domżał- } \\
\text { Drzewicka } \\
\text { i Pasternak, } \\
2004[17]\end{array}$ & $\begin{array}{l}\text { opis zadań pielęgniarki rodzinnej } \\
\text { w zakresie wczesnego wykrywania } \\
\text { ryzyka wystąpienia cukrzycy typu } 2\end{array}$ & $\begin{array}{l}\text { pacjenci; } \\
\mathrm{n}=106\end{array}$ & $\begin{array}{l}\text { analiza do- } \\
\text { kumentacji } \\
\text { pielęgniarskiej } \\
\text { - kwestionariusz } \\
\text { rodziny }\end{array}$ & $\begin{array}{l}\text { u } 98 \% \text { badanych występowat co najmniej jeden czyn- } \\
\text { nik ryzyka. Czynniki ryzyka cukrzycy w badanej grupie } \\
\text { palenie papierosów - 86,7\%; ilościowe i jakościowe } \\
\text { błędy w żywieniu - } 84.9 \% \text {; niski poziom aktywności } \\
\text { fizycznej- 75,4\%; nadwaga - 80,2\% }\end{array}$ \\
\hline 14. & $\begin{array}{l}\text { Sawicka- } \\
\text { Powierza i wsp., } \\
2009[18]\end{array}$ & $\begin{array}{l}\text { ocena wiedzy pacjentów na temat } \\
\text { zasad bezpiecznego stosowania do- } \\
\text { ustnych koagulantów oraz wpływu } \\
\text { edukacji w tym zakresie prowadzo- } \\
\text { nej przez pielęgniarki rodzinne }\end{array}$ & $\begin{array}{l}\text { pacjenci; } \\
\mathrm{n}=25\end{array}$ & $\begin{array}{l}\text { wywiad za po- } \\
\text { mocą ankiety }\end{array}$ & $\begin{array}{l}\text { 1) TTR (przedział terapeutyczny wartości INR - wskaź- } \\
\text { nika protrombinowego) przed edukacją wyniósł } 48 \% \text {, } \\
\text { po edukacji } 52 \% \text {, } \\
\text { 2) TTR istotnie zwiększyt się w grupie osób } 61 .-75 \text {. r.ż. - } \\
\text { 17,96\% po zastosowaniu edukacji przez pielęgniarki } \\
\text { rodzinne }\end{array}$ \\
\hline 15. & $\begin{array}{l}\text { Marcinowicz } \\
\text { i Borzuchowska, } \\
2000[19]\end{array}$ & $\begin{array}{l}\text { poznanie opinii pacjentów na temat } \\
\text { opieki pielęgniarskiej w miejscu za- } \\
\text { mieszkania pacjenta, w sytuacji gdy } \\
\text { kontrakt lekarza rodzinnego obej- } \\
\text { mował świadczenia pielęgniarki śro- } \\
\text { dowiskowej/rodzinnej }\end{array}$ & $\begin{array}{l}\text { pacjenci; } \\
\mathrm{n}=1000\end{array}$ & $\begin{array}{l}\text { kwestionariusz } \\
\text { wywiadu }\end{array}$ & $\begin{array}{l}\text { 1) } 16,3 \% \text { osób skorzystało z wizyty domowej pielę- } \\
\text { gniarki środowiskowej/rodzinnej, } \\
\text { 2) pacjenci oczekują od pielęgniarki przede wszystkim } \\
\text { niezbędnych zabiegów pielęgniarskich ( } 95 \% \text { wska- } \\
\text { zań), opieki nad chorym w domu ( } 80,5 \%) \text {, informacji } \\
\text { o zdrowiu ( } 72 \%)\end{array}$ \\
\hline 16. & $\begin{array}{l}\text { Misiak, } 2005 \\
\text { [20] }\end{array}$ & $\begin{array}{l}\text { badanie pinii pacjentów o świadcze- } \\
\text { niach udzielanych przez pielęgniarki } \\
\text { środowiskowo-rodzinne ze szczegól- } \\
\text { nym zwróceniem uwagi na wizyty } \\
\text { profilaktyczne }\end{array}$ & $\begin{array}{l}\text { pacjenci; } \\
\mathrm{n}=99\end{array}$ & $\begin{array}{l}\text { badanie sonda- } \\
\text { żowe / przegląd } \\
\text { dokumentacji } \\
\text { medycznej / } \\
\text { wtórna analiza } \\
\text { danych }\end{array}$ & $\begin{array}{l}\text { 1) } 56,49 \% \text { badanych wizyty profilaktyczne ocenito } \\
\text { bardzo dobrze, } 30 \% \text { dobrze, } \\
\text { 2) } 100 \% \text { pacjentów oczekuje realizacji zleceń, } 22,72 \% \\
\text { pomocy w chorobie, } 4,54 \% \text { oczekuje edukacji nt. } \\
\text { zdrowia }\end{array}$ \\
\hline 17. & $\begin{array}{l}\text { Marcinowicz } \\
\text { i wsp., } 2009 \text { [21] }\end{array}$ & $\begin{array}{l}\text { ocena udziału pielęgniarek rodzin- } \\
\text { nych w wizytach domowych w kon- } \\
\text { tekście organizacyjnych i prawnych } \\
\text { zmian w świadczeniu usług, tzn. } \\
\text { analiza roli pielęgniarek rodzinnych } \\
\text { zatrudnionych przez lekarzy rodzin- } \\
\text { nych (1998) w porównaniu z pielę- } \\
\text { gniarkami rodzinnymi pracującymi } \\
\text { w samodzielnych podmiotach pro- } \\
\text { wadzonych przez pielęgniarki (2002 } \\
\text { i 2006) }\end{array}$ & $\begin{array}{l}\text { pacjenci - } \\
1998 \mathrm{r} . ; \\
\mathrm{n}=1000 \\
\text { pacjenci - } \\
2002 \mathrm{r} . ; \\
\mathrm{n}=1000 \\
\text { pacjenci - } \\
2006 \mathrm{r} \text {; } \\
\mathrm{n}=1000\end{array}$ & $\begin{array}{l}\text { badanie prze- } \\
\text { krojowe / } \\
\text { kwestionariusz } \\
\text { wywiadu }\end{array}$ & $\begin{array}{l}\text { 1) wzrost odsetka wizyt domowych z } 12,8 \% \text { do } 30,0 \% \\
\text { pomiędzy badaniem I a II (w odstępach 4-letnich), } \\
\text { 2) zmniejszyt się odsetek pacjentów, których pielę- } \\
\text { gniarka rodzinna nigdy nie odwiedziła w domu z } 71,8 \% \\
\text { w I badaniu do } 46,5 \% \text { w II badaniu }\end{array}$ \\
\hline \multicolumn{3}{|c|}{ Ogółem } & 33502 & & \\
\hline
\end{tabular}

Rodzinnej, Health \& Social Care in the Community, Polski Merkuriusz Lekarski, Pielęgniarstwo i Zdrowie Publiczne.

\section{Rodzaje i zakres badań empirycznych w pielęgniarstwie rodzinnym}

W celu rzetelnego przedstawienia analizowanych publikacji prace podzielono na 3 grupy respondentów, wśród których przeprowadzane zostały badania: 1) pacjentów - odbiorców świadczeń; 2) realizatorów świadczeń, tj. pielęgniarki rodzinne; 3) lekarzy rodzinnych oraz opiekunów nieformalnych osób objętych opieką pielęgniarki rodzinnej z uwzględnieniem relacji pielęgniarka-pacjent. Pacjenci korzystający z usług pielęgniarki rodzinnej w zdecydowanej większości byli zadowoleni z jakości tych świadczeń. Badania wskazują, że zadania wypełniane przez pielęgniarkę rodzinną koncentrowały się głównie wokół choroby i dotyczyły świadczeń leczniczych i diagnostycznych. Wizyty domowe realizowane były przede wszystkim wśród osób starszych i samotnych. Szczegółową analizę celów badania i głównych wyników badań przeprowadzonych w grupie pacjentów przedstawiono w tabeli 1. 
TABELA 2. Przegląd badań empirycznych w obszarze pielęgniarstwa rodzinnego w grupie pielęgniarek - realizatorów świadczeń podstawowej opieki zdrowotnej (POZ) w latach 1995-2015

\begin{tabular}{|c|c|c|c|c|c|}
\hline Lp. & Autorzy & Cel pracy & $\begin{array}{c}\text { Grupa } \\
\text { i liczba } \\
\text { badanych }\end{array}$ & $\begin{array}{l}\text { Metoda / } \\
\text { narzędzie } \\
\text { badawcze }\end{array}$ & Główne wyniki badań \\
\hline
\end{tabular}

1. Walas i wsp., ocena satysfakcji pielęgniarek śro- pielę2007 [22] dowiskowych/rodzinnych z wykonywanej pracy pielę-

gniarki; $\mathrm{n}=114$ badanie ankietowe

1) $98 \%$ badanych pielęgniarek wykonywało dodatkowo pracę w rejestracji, 37\% wykonywało czynności w gabinecie lekarskim,

2) $97,4 \%$ ankietowanych pielęgniarek wysoko ocenito współpracę z pacjentem i jego rodzina,

3) $85,9 \%$ pielęgniarek za główny problem w ich pracy uznało ilość wykonywanych zleceń lekarskich, 76,8\% zbyt małą możliwość samodzielności zawodowej, $64,9 \%$ - zbyt niskie wynagrodzenia

2. Studnikiwsp., porównanie wybranych elementów pielę2013 [23]

pracy i sytuacji zawodowej pielę- gniarki gniarek środowiskowo-rodzinnych środowii pielęgniarek opieki długotermi- skowe; nowej

$\mathrm{n}=50$ autorski kwestionariusz ankiety

pielęgniarki OPD;

$\mathrm{n}=50$
1) pielęgniarki z obu grup różnicuje zakres udzielanych świadczeń, liczba pacjentów, czas opieki,

2) pielęgniarki z obu grup wskazują na konieczność stałego podnoszenia kwalifikacji,

3) tylko $40 \%$ ankietowanych uważa, że pracodawca dostarcza niezbędnych środków do pracy
3. Doroszkiewicz ocena stopnia zadowolenia piele- pielęi Bień, 2004 [24] gniarek środowiskowych z pracy gniarki; w środowisku ludzi starszych wraz $n=113$ z określeniem jego uwarunkowań autorski kwestionariusz ankiety

1) wg $82 \%$ pieleggniarek warunkiem zwiększonej satysfakcji z pracy bytaby mniejsza liczba podopiecznych, 81,9\% uznało jako źródło niskiej satysfakcji niedocenianie finansowe, 74,7\% obciążenia administracyjne, 2) istotny wpływ na satysfakcję z wykonywanej pracy dla $31 \%$ respondentek stanowita wtaściwa liczba zatrudnionych pielęgniarek

4. Czarnecka identyfikacja wybranych zagrożeń pielęi wsp., 2014 [25] występujących w pracy pielęgnia- gniarki; rek/pielęgniarzy środowiskowych $\quad n=100$ sondaż diagnostyczny / ankieta / autorski kwestionariusz ankiety

1) $48 \%$ badanych określiło pracę w środowisku jako ciężką,

2) najliczniejsza grupa - $88 \%$ jako czynnik obciążający uznała małe zarobki, $87 \%$ - zbyt duże oczekiwania środowiska, 85\% niedostateczną liczbę zatrudnionych, $84 \%$ obciążenia wynikające $z$ dotarcia do pacjenta, $83 \%$ obciążenia psychiczne, $60 \%$ obciążenia biurowe

5. Kułagowska poznanie warunków pracy, a w szcze- pielęi Kosińska, 2010 gólności zagrożeń podczas prac gniarki; [26] wykonywanych przez pielegniarki $\mathrm{n}=86$

autorski kwestionariusz ankiety

1) średni czas poświęcany na przemieszczanie się pomiędzy środowiskami wynosi $2 \mathrm{~h}(36 \%)$,

2) $85 \%$ świadczeń wykonywanych w stosunku do pacjenta stanowią czynności pielęgnacyjno-lecznicze, $69 \%$ zadań dotyczy świadczeń pielęgnacyjno-higienicznych, 58\% stanowią świadczenia diagnostyczne, 3) $73 \%$ pielęgniarek wskazało na szczególne obciążenia psychiczne związane z wykonywaną praca, $80 \%$ pielęgniarek odczuwa dolegliwości bólowe w obrębie układu mięśniowo-szkieletowego podczas wykonywania obowiązków

6. Dębska analiza niektórych uwarunkowań ze- pielęi Cepuch, 2008 społu wypalenia zawodowego u pie- gniarki; [27] lęgniarek pracujących w zakładach $\mathrm{n}=35$ podstawowej opieki zdrowotnej standaryzowane 1) stosując Kwestionariusz Wypalenia Zawodowego, skale i kwestio- $\quad x=38,5$ pielęgniarek wskazało na poczucie własnej nariusz wartości,
2) wyczerpanie emocjonalne występuje $u x=22,8$,

3) najczęściej stosowaną strategią radzenia sobie ze stresem jest koncentracja na zadaniu $x=16,1$, natomiast ucieczka i unikanie znalazła się na drugim miejscu $z$ wartością $x=11,5$

7. Karniej i wsp., stwierdzenie stopnia zaintereso- pielę2012 [28] wania pielęgniarek i połoznych gniarki podnoszeniem kompetencji z za- i położne; kresu wykonywanego zawodu, ale $n=631$ także z innych obszarów, których zrozumienie wydaje się niezbędne dla prawidłowego funkcjonowania w systemie współczesnej opieki zdrowotnej ankieta struktu- 1) 505 badanych podnosi swoje kwalifikacje zaworalna dowe

2) 366 osób jako formę podnoszenia kwalifikacji wskazało kursy i szkolenia, 142 wyższe studia,

3) 222 osoby podnosito swoje kwalifikacje w ostatnim roku 


\begin{tabular}{llll} 
Lp. Autorzy & $\begin{array}{c}\text { Grupa } \\
\text { i liczba } \\
\text { badanych }\end{array}$ & $\begin{array}{c}\text { Metoda / } \\
\text { narzędzie } \\
\text { badawcze }\end{array}$ & Gtówne wyniki badań \\
\hline
\end{tabular}

8. Leszczyńska poznanie opinii pielęgniarek śro- pielęi wsp., 2007 [29] dowiskowo-rodzinnych na temat gniarki; funkcjonowania podstawowej opieki $n=81$ zdrowotnej badanie surveyowe / autorski kwestionariusz ankiety

1) $10 \%$ pielęgniarek realizowało samodzielne kontrakty z Narodowym Funduszem Zdrowia,

2) $75 \%$ pielęgniarek uznało, iż wynagrodzenie za prace w POZ jest niewystarczające, tylko 14\% stwierdziło, że zarabia dobrze,

3) $70 \%$ pielęgniarek wysoko ocenito stosunki z pacjentami i innymi pielęgniarkami

9. Mirczak i wsp., porównanie percepcji różnych form pielę2011 [30] przemocy wobec ludzi starszych gniarki; przez pielęgniarki środowiskowe $\mathrm{n}=184$ i kliniczne oraz zbadanie czynników warunkujących to postrzeganie autorski kwestionariusz ankiety

1) zaledwie $19 \%$ pielęgniarek środowiskowych zauważa problem samozaniedbania wśród starszych pacjentów,

2) tylko $7,9 \%$ uznaje jako problem porzucenie osoby starszej,

3) zaniedbanie i zaniechanie dostrzega tylko $12,9 \%$ pielęgniarek środowiskowych

\section{Stefanowicz próba oceny, czy i w jakim zakresie pielę- i wsp., 2010 [31] pielęgniarki środowiskowo-rodzin- gniarki; ne prowadzą edukację zdrowotną $\mathrm{n}=230$ wśród swoich pacjentów; czy na po- dejmowane działania edukacyjne mają wpływ kwalifikacje zawodowe, ich miejsce pracy i forma zatrud- nienie}

11. Stońska i wsp., ocena poziomu wybranych elemen- pielę2007 [32] tów wiedzy pielęgniarek $\mathrm{POZ}$, ade- gniarki; kwatności dokonywanej przez nie $n=500$ oceny własnych kompetencji oraz określenie częstości udzielanych świadczeń z zakresu poradnictwa dotyczącego dwóch behawioralnych czynników ryzyka chorób układu krążenia

12. Mojsa i wsp., poznanie wiedzy pielęgniarek pod- pielęstawowej opieki zdrowotnej na te- gniarki mat czynników ryzyka chorób ukła- $n=146$ du krążenia (CHUK)

sondaż diagnostyczny / autorski kwestionariusz ankiety

1) $83 \%$ pielęgniarek potwierdziło udzielanie porad nt. stylu życia, czynników ryzyka chorób,

2) $64 \%$ porad edukacyjnych pielęgniarka udziela z własnej inicjatywy, 18,6\% na prośbę pacjenta, 3) najczęściej $(85,7 \%)$ porad edukacyjnych udzielają pielęgniarki ze specjalizacją, rzadziej $(66,4 \%)$ z kursem kwalifikacyjnym, a najmniej (24\%) pielęgniarki "ogólne"

wywiad bezpo- 1) tylko 4,2\% pielęgniarek poprawnie odpowiedziało średni na pytania dotyczące kwestii prawidłowego żywienia, 2) $32,2 \%$ badanych udzielita poprawnie odpowiedzi na pytania dotyczące wskaźnika masy ciała,

3) minimalną dawkę aktywności fizycznej niezbędnej do zapobiegania chorobom układu krążenia prawidłowo określito $50,3 \%$ badanych pielęgniarek, 4) 9,2\% pielęgniarek „przeceniło" swoją wiedzę dotyczącą poradnictwa żywieniowego

sondaż diagno- 1) 15,1\% pielęgniarek wymieniło 4 główne czynniki styczny, techni- ryzyka CHUK,

ka ankiety $\quad$ 2) $11,6 \%$ wymieniło 3 główne czynniki CHUK,

3) $18,5 \%$ wymieniło 2 główne czynniki ryzyka CHUK,

4) $92,5 \%$ badanych uznało, iż potrzebuje dokształcania w zakresie profilaktyki CHUK

13. Doroszkiewicz określenie kategorii świadczeń pielęi Bień, 2005 [34] realizowanych przez pielęgniarki gniarki; środowiskowe w stosunku do osób $\mathrm{n}=100$ starszych z uwzględnieniem różnych form organizacyjnych (publiczny i niepubliczny zakład opieki zdrowotnej) anonimowy, autorski kwestionariusz ankiety
1) wśród zadań realizowanych w stosunku do osób starszych zaobserwowano istotną przewagę zadań leczniczych (na zlecenie lekarza) - 95\%; świadczenia diagnostyczne realizowało $78 \%$ pielęgniarek, 2) nie zaobserwowano istotnych różnic pomiędzy rodzajami świadczeń realizowanymi przez pielęgniarki pracujące w sektorze publicznym i niepublicznym
W 17 badaniach obejmujących łącznie populację 33502 pacjentów - odbiorców świadczeń POZ jedno badanie było przeprowadzone na reprezentatywnej grupie pacjentów [13], pozostałe miały charakter badań przekrojowych. W 3 badaniach autorzy zastosowali standaryzowane narzędzia badawcze $[11,13,14]$, a w jednym [20] dokonano przeglądu dokumentacji medycznej.

Pielęgniarki rodzinne oprócz zadań wynikających z zakresu ich kompetencji często wykonują inne czynności pozamedyczne (np. rejestracja czy obowiązki administracyjne, które w ich ocenie znacznie utrudniają im prawidłową organizację pracy).
Większość pielęgniarek stwierdziła, że odczuwają ograniczenia w samodzielności zawodowej, a jako główne źródło obniżonej satysfakcji zawodowej wskazały zbyt niskie wynagrodzenia i zbyt dużą populację pacjentów, którym muszą zapewnić opiekę. Szczegółową analizę celów badania i głównych wyników badań przeprowadzonych wśród pielęgniarek rodzinnych przedstawiono w tabeli 2 .

W 13 celowych i przekrojowych badaniach obejmujących łącznie grupę 2520 pielęgniarek - realizatorów świadczeń POZ autorzy wykorzystywali głównie badanie ankietowe z użyciem kwestionariusza ankiety własnej konstrukcji, w jednym 
TABELA 3. Przegląd badań empirycznych w obszarze pielęgniarstwa rodzinnego w grupach: lekarzy rodzinnych, pielęgniarka-pacjent oraz opiekun nieformalny $z$ lat 1995-2015

$\begin{array}{lcl}\text { Lp. Autorzy } & \text { Grupa } & \text { Metoda / } \\ \text { i liczba } & \text { narzędzie } \\ \text { badanych } & \text { badawcze }\end{array}$

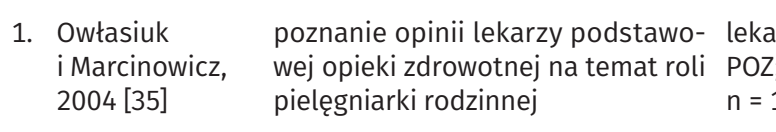

2. Leszczyńska poznanie opinii lekarzy rodzinnych lekarze; i wsp., 2007 [36] na temat sytuacji w POZ (z uwzględ- $n=47$ nieniem kompetencji pielęgniarek środowiskowo-rodzinnych) sondaż diagnostyczny / kwestionariusz ankiety

sondaż diagnostyczny / kwestionariusz ankiety

94\% lekarzy uznało, że najważniejszą funkcją pielęgniarek POZ jest promocja zdrowia i rola terapeutyczna, profilaktyczna - 90,5\%, wychowawcza - 88,8\%, opiekuńcza - 86,2\%, rehabilitacyjna - 85,3\%

1) wysoko oceniono samodzielność pielęgniarek $80 \%$ ocen dobrych lub bardzo dobrych,

2) współudział w procesie diagnostyczno-leczniczym - $82 \%$ ocen dobrych lub bardzo dobrych,

3) rozpoznawanie i ocena potrzeb zdrowotnych - $80 \%$ ocen dobrych lub bardzo dobrych

3. Misiak, 2004 [37] wypracowanie skutecznego narzę- pielędzia badania jakości wizyt pielęgniarek $w$ domu starszego pacjenta kwestionariusz / analiza dokumentacji pielę$\mathrm{n}=22$ pacjenci; gniarskiej $\mathrm{n}=118$
1) $93,55 \%$ badanych pielęgniarek miało ukończony kurs kwalifikacyjny,

2) ponad $80 \%$ respondentów oczekuje od pielęgniarki realizacji zleceń lekarskich, prawie $80 \%$ badanych pacjentów oceniła spełnianie oczekiwań przez pielęgniarki POZ na 5 (w skali 1-5)

4. Doroszkiewicz uzyskanie odpowiedzi na pytanie: lekarze i Bień, 2007 [38] czy forma zatrudnienia pielęgniarek rodzinni; środowiskowych w podstawowej $n=104$ autorski kwestionariusz ankiety opiece zdrowotnej wpływa na jakość pracy zespołowej w opiece nad osobami starszymi?

1) $33,3 \%$ lekarzy zatrudniających pielęgniarki oceniło współpracę z nimi jako bardzo dobrą,

2) wizyty u osób starszych w jednostkach zatrudniających pielęgniarki odbyły się wśród 47,8\% pacjentów, a w przypadku współpracy z samodzielnymi podmiotami pielęgniarskimi wśród 22,9\% osób starszych, 3) problemy geriatryczne częściej były omawiane w jednostkach, w których lekarze zatrudniają pielęgniarki - 84,1\% w porównaniu z jednostkami współpracującymi - 42,8\%

5. Strzelecka poznanie problemów, z jakimi spo- pacjenci; i Zieliński, 2012 tykają się pacjenci niepełnosprawni $\mathrm{n}=200$ [39] oraz ich oczekiwań w zakresie opieki pielępielęgniarskiej w podstawowej opie- gniarki; ce zdrowotnej autorskie kwestionariusze ankiet (odrębne dla pacjentów i pielęgniarek)
1) $52 \%$ pielęgniarek ma na swoich listach $21-40$ osób wymagających stałej opieki,

2) 45\% wizyt w tygodniu dotyczyła pacjentów niepełnosprawnych,

3) wizyta u pacjenta niepełnosprawnego w 76\% przypadków trwała 16-30 min,

4) $84 \%$ osób oczekuje wydłużenia czasu trwania wizyty pielęgniarki $\mathrm{POZ}$,

5) rodzaje zadań to: $83 \%$ - edukacja, $75 \%$ - zalecenia dietetyczne, $69 \%$ - iniekcje, $61 \%$ - drobne zabiegi
6. Bień i wsp., 2008 [40]

weryfikacja tezy, że korzystanie opiekunoz różnego typu dostępnych usług wie osób jest dostosowane pod względem powyżej profilu i zakresu do poziomu nie- 65. r.ż.; sprawności i potrzeb osób nie- $n=1000$ sprawnych w podeszłym wieku

7. Zaczyk i wsp., wskazanie zadań dla pielęgniarki pacjenci; 2011 [41] środowiskowej wyznaczonych przez $n=6$ potrzeby i oczekiwania podopiecz- pielęnych w starszym wieku gniarki; $\mathrm{n}=11$

1) $41 \%$ badanych skorzystało ze świadczeń pielęgniarskich, z tego 58\% poważnie niesprawnych, a 21\% CAT (Common Assesment Tool), nieznacznie niesprawnych,

wywiady bezpo- 2) niemal wszystkie osoby z poważniejszym upośleśrednie dzeniem sprawności były odwiedzane przez pielęgniarkę w ich domu

zogniskowane wywiady grupowe

1) pacjenci w starszym wieku postrzegają pielęgniarki środowiskowe jako osoby o największym znaczeniu w opiece środowiskowej nad ludźmi starszymi,

2) wykazano istotną rolę pielęgniarki jako źródła wsparcia, informacji, wsparcia emocjonalnego,

3) wykazano istotność współpracy pielęgniarki z rodziną w celu zaangażowania osób z najbliższego otoczenia pacjenta w opiekę nad nim

8. Mroczeki wsp., ocena realizacji obowiązujących pacjenci; 2011 [42] dro- pielęwotnej w opinii pielęgniarek środo- gniarki;

autorski kwestionariusz ankiety
1) $73,2 \%$ badanych pielęgniarek uważa, że obecna forma realizacji programów profilaktycznych jest niewystarczająca,

2) program profilaktyki gruźlicy realizuje $67,4 \%$ badanych pielęgniarek,

3) $30 \%$ świadczeniobiorców nic nie wiedziało o programach profilaktycznych,

4) $48 \%$ badanych pielęgniarek zrealizowało wizyty w środowiskach szczególnie zagrożonych gruźlicą 


\begin{tabular}{|c|c|c|c|c|c|}
\hline Lp. & Autorzy & Cel pracy & $\begin{array}{c}\text { Grupa } \\
\text { i liczba } \\
\text { badanych }\end{array}$ & $\begin{array}{l}\text { Metoda / } \\
\text { narzędzie } \\
\text { badawcze }\end{array}$ & Główne wyniki badań \\
\hline 9. & $\begin{array}{l}\text { Misiak i wsp., } \\
2005 \text { [43] }\end{array}$ & $\begin{array}{l}\text { określenie struktury świadczeń pie- } \\
\text { lęgniarek środowiskowo-rodzinnych, } \\
\text { które pracując z rodziną, spotykają } \\
\text { się z podopiecznymi w różnym wie- } \\
\text { ku, oraz konfrontacja stereotypu } \\
\text { pielęgniarki wykonującej świadcze- } \\
\text { nia zabiegowe na zlecenie lekarza } \\
\text { z rzeczywistymi danymi, które ilu- } \\
\text { strują prace pielęgniarek środowi- } \\
\text { skowo-rodzinnych }\end{array}$ & $\begin{array}{l}\text { pielę- } \\
\text { gniarki; } \\
\mathrm{n}=22 \\
\text { pacjenci; } \\
\mathrm{n}=118\end{array}$ & $\begin{array}{l}\text { ankieta / analiza } \\
\text { dokumentacji } \\
\text { medycznej }\end{array}$ & $\begin{array}{l}\text { 1) } 63,76 \% \text { wszystkich świadczeń realizowanych przez } \\
\text { pielęgniarki dotyczy osób powyżej } 64 \text {. r.ż. (z tego } \\
74,11 \% \text { świadczeń diagnostycznych, } 67,57 \% \text { świad- } \\
\text { czeń pielęgnacyjnych, } 59,90 \% \text { świadczeń zabiego- } \\
\text { wych), } \\
\text { 2) oczekiwania pacjentów wobec pielęgniarki rodzin- } \\
\text { nej koncentrowały się wokół choroby, } \\
\text { 3) pielęgniarki realizują świadczenia zzakresu promo- } \\
\text { cji zdrowia najczęściej z własnej inicjatywy }\end{array}$ \\
\hline & $\begin{array}{l}\text { Zdżalik i wsp., } \\
2015 \text { [44] }\end{array}$ & $\begin{array}{l}\text { porównanie kompetencji pielęgniar- } \\
\text { ki zdrowia rodziny (FHN) i pielęgniar- } \\
\text { ki podstawowej opieki zdrowotnej } \\
\text { (POZ) w ramach projektu „Pielęgno- } \\
\text { wanie zdrowia rodziny we Wspólno- } \\
\text { tach Europejskich” }\end{array}$ & $\begin{array}{l}\text { dokumen- } \\
\text { ty: akty } \\
\text { prawne; } \\
\mathrm{n}=4 \\
\text { akty } \\
\text { etyczne; } \\
\mathrm{n}=1\end{array}$ & $\begin{array}{l}\text { dokumento- } \\
\text { skopia - analiza } \\
\text { piśmiennictwa }\end{array}$ & $\begin{array}{l}\text { 1) pielęgniarka POZ i FHN realizują zadania samo- } \\
\text { dzielnie i odpowiedzialnie, zgodnie z kompetencjami } \\
\text { i kwalifikacjami, } \\
\text { 2) pielęgniarka FHN i POZ realizują zadania w stosunku } \\
\text { do rodzin, jednostek w różnym stanie zdrowia, } \\
\text { 3) pielęgniarka POZ i FHN dba o rozwój zawodowy } \\
\text { i jakość wykonywanych świadczeń, biorąc pod uwagę } \\
\text { potrzeby podopiecznych }\end{array}$ \\
\hline
\end{tabular}

zastosowano standaryzowane skale pomiarowe [27], a w jednej pracy narzędziem badawczym był wywiad bezpośredni [32].

Zarówno świadczeniobiorcy, jak i współpracownicy (lekarze) oczekują od pielęgniarki rodzinnej pełnego zaangażowania w sprawowanie opieki nad pacjentami. Ze strony zarówno pacjentów, jaki opiekunów nieformalnych osób wymagających pomocy oczekuje się przede wszystkim dostępności do świadczeń i wydłużenia czasu wizyt domowych, zwłaszcza w stosunku do osób niepełnosprawnych. Lekarze rodzinni w analizowanych badaniach bardzo wysoko ocenili kompetencje, kwalifikacje i wiedzę pielęgniarek rodzinnych oraz ich udział w procesie terapeutyczno-leczniczym. Szczegółową analizę celów i głównych wyników badań przeprowadzonych wśród lekarzy rodzinnych, pielęgniarek/pacjentów i opiekunów nieformalnych przedstawiono w tabeli 3 .

Dziesięć badań empirycznych zostało przeprowadzonych w następujących grupach związanych z opieką nad pacjentem w miejscu zamieszkania: lekarze rodzinni (łącznie $\mathrm{n}=267)[35,36,38]$, badania $\mathrm{w}$ perspektywie pielęgniarkapacjent [37, 39, 41, 42, 43], opiekunowie osób powyżej 65. r.ż. $(n=1000)$ [40]. Jedno badanie dotyczyło analizy dokumentów w odniesieniu do pielęgniarek rodzinnych [44].

Spośród 40 prac oryginalnych większość $(62,5 \%)$ stanowiły prace, w których główną metodą badawczą był sondaż diagnostyczny z zastosowaniem autorskiego kwestionariusza ankiety $[5,6,7,8,9,11,13,14,16,18,22,23,24,26,28,29,30,31,33$, $34,35,36,38,39,42]$. Kwestionariusz wywiadu jako narzędzie badawcze był wykorzystany w 7 pracach $[10,12,15,19,21,32$, 40]. Autorzy jednej pracy zbierali dane za pomocą zogniskowanych wywiadów grupowych [41]. W jednej pracy zastosowano dokumentoskopię oraz analizę piśmiennictwa [44]. Metodę badawczą polegającą na analizie dokumentacji medycznej zastosowano w 4 pracach $[17,20,37,43]$. Ponadto w 2 pracach do zbierania danych wykorzystano standaryzowane kwestionariusze i skale [25, 27]. Grupę badawczą stanowili pacjenci, pielęgniarki, lekarze rodzinni oraz opiekunowie nieformalni osób objętych opieką domową. Liczebność grup wynosiła od 6 [41] do 21600 osób [9].

\section{DYSKUSJA}

Kształcenie pielęgniarek na poziomie wyższym oraz możliwość współpracy międzynarodowej w obszarze nauki i praktyki daje szansę zwiększenia potencjału badawczego i rozwoju badań naukowych w pielęgniarstwie [3]. Jednak prezentowany przegląd dowodzi, że wkład w rozwój pielęgniarstwa rodzinnego jako nauki pozostaje ograniczony do stosunkowo niewielkiej liczby badań obejmujących kilka zakresów tematycznych. Dominują badania skupione wokół opieki nad konkretną grupą pacjentów, zwłaszcza w wieku starszym. Prawdopodobnym powodem tego może być sytuacja demograficzna Polski, wzrost odsetka ludzi w wieku podeszłym i rozpowszechnienie występowania u nich wielu problemów zdrowotnych, z którymi musi zmierzyć się pielęgniarka rodzinna [14]. Biorąc pod uwagę aktualny zakres zadań i kompetencji, jakie posiada pielęgniarka rodzinna, oraz jej bezpośredni i długotrwały kontakt z pacjentem i jego rodziną, uzasadnione wydają się badania naukowe dotyczące samodzielności zawodowej tej grupy osób [41]. Wzmocnienie samodzielności zawodowej pielęgniarek rodzinnych zgodnie z rekomendacjami Światowej Organizacji Zdrowia mogłoby przyczynić się do lepszej dostępności do świadczeń oraz wzrostu znaczenia profilaktyki i promocji zdrowia w społeczeństwie [44].

Przedstawiony przegląd piśmiennictwa podsumowuje literaturę dotyczącą pielęgniarstwa rodzinnego w zakresie prac empirycznych. Pielęgniarstwo jako odrębna dyscyplina naukowa jest na początkowym etapie jej rozwoju, jednak charakter pielęgniarstwa rodzinnego i jego złożoność stwarzają wiele możliwości do prowadzenia dalszych badań obejmujących zakres działalności zawodowej. Sporadyczne wykorzystanie 
metod i technik jakościowych przez polskich badaczy nie sprzyja rozwojowi wiedzy o pielęgniarstwie rodzinnym. Jedną z postulowanych metodologii w pielęgniarstwie jest także wykorzystanie opisów przypadków [45].

\section{WNIOSKI}

1. Widoczny jest brak różnorodności metodologicznej w podejmowanej tematyce badawczej. W przeważającej części prac stosowano metodę ilościową z wykorzystaniem autorskiego kwestionariusza ankiety. Podejście jakościowe jest wykorzystywane przez nielicznych badaczy.

2. Obszarem zainteresowania badaczy są kwestie związane z opieką pielęgniarki rodzinnej wobec osób starszych. $\mathrm{W}$ analizowanych pracach zupełnie zmarginalizowana jest rola pielęgniarki rodzinnej w opiece nad odbiorcami świadczeń w wieku rozwojowym czy wieku produkcyjnym. Pielęgniarki rodzinne wykonują niewiele zadań samodzielnych, wynikających z posiadanych kompetencji.

3. Zakres badań empirycznych w pielęgniarstwie rodzinnym skoncentrowany jest na opiniach, oczekiwaniach oraz wiedzy badanych pacjentów, a także satysfakcji, wiedzy i opinii pielęgniarek w zróżnicowanych tematycznie zagadnieniach.

4. Rzetelne badania naukowe oparte na dowodach (evidence-based research) są potrzebne, aby dostarczyć dalszej wiedzy na temat roli pielęgniarki rodzinnej i efektów jej pracy wpływających na jakość opieki nad pacjentem.

\section{PIŚMIENNICTWO}

1. Godycki-Ćwirko M, Nowak P, Windak A, Kosiek K. Zarys historii medy cyny rodzinnej w Polsce. In: Latkowski JB, Lukas W, editors. Medycyna rodzinna. Warszawa: PZWL; 2009.

2. Panczyk M, Belowska J, Zarzeka A, Żmuda-Trzebiatowska H, Kot-Doniec B, Gotlib J. Evidence-Based Practice Profile Questionnaire - reconstructive accuracy of the questionnaire to the study of the knowledge, attitudes and skills in the area of EBM and EBP in a group of Polish nurses. Probl Pielęg 2015;23(3):314-23. doi: 10.5603/PP.2015.0052.

3. Smith LN. The role of nursing and the impact of nursing research in Europe. Probl Pielęg 2007;15(1):59-63.

4. Moher D, Liberati A, Tetzlaff J, Altman DG. Preferred reporting items for systematic reviews and meta-analyses: The PRISMA Statement. PLoS Med 2009;6(7):e1000097. doi: 10.1371/journal.pmed1000097.

5. Oskędra I, Zych B, Skorupska-Król A, Puziara B. Satysfakcja pacjentów w podeszłym wieku z opieki środowiskowej świadczonej w ramach podstawowej opieki zdrowotnej. Probl Pielęg 2015;23(2):203-7. doi: 10.5603/ PP.2015.0034.

6. Derkacz M, Chmiel-Perzyńska I, Kowal A, Grywalska A, Michałojć-Derkacz M, Pawłowska B. Ocena satysfakcji pacjentów z usług świadczonych przez zakłady Podstawowej Opieki Zdrowotnej małych miast oraz wsi Polski południowo-wschodniej. Med Ogólna 2010;16(XLV)4:463-73.

7. Leszczyńska M, Krajewska-Kułak E, Łukaszuk C, Sobolewski M, Kędziora-Kornatowska K, Borzuchowska A. Opinia pacjentów o jakości usług podstawowej opieki zdrowotnej na terenie miasta Jasła i jego okolic. Probl Hig Epidemiol 2007;88(3):277-85.

8. Brodzińska M, Modzelewska K, Stachowska M, Talarska D. Stratyfikacja czynników determinujących opinię o jakości świadczeń w zakresie kompetencji pielęgniarki podstawowej opieki zdrowotnej. Doniesienia wstępne. Probl Hig Epidemiol 2010;91(2):303-7.
9. Piotrowski W, Polakowska M. Dostępność usług medycznych na wsi i w mieście - badanie Wobasz. Med Ogólna 2010;16(4):487-95.

10. Marcinowicz J, Borzuchowska A, Rybaczuk M. Wizy ty domowe lekarzy i pielęgniarek rodzinnych wśród starszych podopiecznych: wyniki 4-letniej analizy. Gerontol Pol 2004;12(1):32-6.

11. Doroszkiewicz H, Bień B. Środowiskowa opieka pielęgniarska nad osobami w późnej starości. Gerontol Pol 2003;11(1):22-6.

12. Bień B. Health care for the elderly living in the rural area of Poland. Przegl Lek 2002;59(4-5):211-5.

13. Borowiak E, Kostka J, Kostka T. Comparative analysis of the expected demands for nursing care services among older people from urban, rural and institutional environments. Clin Interv Aging 2015;10:405-12. doi: 10.2147/CIA.S72534.

14. Wojszel B, Bień B. The gigants of geriatrics in the community dwelling elderly - the challenge for the primary health care. Przegl Lek 2002;59(4-5): 216-21.

15. Kurowska K, Wrońska I. Potrzeby zdrowotne podopiecznych w świetle badań pielęgniarek środowiskowo-rodzinnych. Zdr Publ 2005;115(1):4952.

16. Szczerbińska K, Malinowska-Cieślik M, Piórecka B, Giustini M. How to effectively change behaviours of patients an old age. Przegl Lek 2011;68(12):1183-9.

17. Domżał-Drzewicka R., Pasternak K. The tasks of a community nurse in the process of an early detection of type 2 diabetes. Ann UMCS Sect D 2004;59(1):481-4.

18. Sawicka-Powierza J, Ołtarzewska AM, Chlabicz S, Dzadkowska-Rogowska D, Marcinowicz L. Educational role of community nurse in care of patients treated with oral anticoagulation therapy. Pol Merkur Lekarski 2009;26(155):636-9.

19. Marcinowicz L, Borzuchowska A. Pielęgniarstwo środowiskowe/rodzinne w nowym modelu opieki zdrowotnej. Probl Med Rodz 2000;2(1):41-5.

20. Misiak K. Świadczenia pielęgniarskie u ludzi w podeszłym wieku na przykładzie analizy pracy pielęgniarek środowiskowo-rodzinnych. Zdr Publ 2005;115(1):68-70.

21. Marcinowicz L, Chlabicz S, Konstantynowicz J, Gugnowski Z. Involvement of family nurses in home visits during an 8-year period encompassing primary healthcare reforms in Poland. Health Soc Care Community 2009;17(4):327-34. doi: 10.1111/j.1365-2524.2008.00824.x.

22. Walas L, Kachaniuk H, Kusiak L, Fidecki W, Sadurska A, Wysokiński M. Satysfakcja zawodowa pielęgniarek środowiskowych/rodzinnych. Zdr Publ 2007;117(1):32-5.

23. Studnik A, Pierchała A, Wójta-Kempa M. Porównanie wybranych elementów pracy i sytuacji zawodowej pielęgniarek opieki długoterminowej i pielęgniarek środowiskowo-rodzinnych. Piel Zdr Publ 2013;3(2): 143-53.

24. Doroszkiewicz H, Bień B. Uwarunkowania satysfakcji zawodowej pielęgniarek środowiskowych z opieki nad ludźmi starszymi. Gerontol Pol 2004;12(1):37-43.

25. Czarnecka J, Sienkiewicz Z, Kobos E, Wójcik G, Krupniewicz A. Risks associated with the work of district nurses. Pielęg Pol 2014;(4):296-301.

26. Kułagowska E, Kosińska M. Warunki pracy pielęgniarek środowiskowo-rodzinnych. Med Pracy 2010;61(6):641-7.

27. Dębska G, Cepuch G. Wypalenie zawodowe u pielęgniarek pracujących w zakładach podstawowej opieki zdrowotnej. Probl Pielęg 2008;16(3): 273-9.

28. Karniej P, Łyś D, Grzebieluch J. Wpływ kompetencji pracowników medycznych na funkcjonowanie praktyki lekarza rodzinnego. Fam Med Primary Care Rev 2012;14(1):24-8.

29. Leszczyńska M, Krajewska-Kułak E, Łukaszuk C, Sobolewski M, Kędziora-Kornatowska K, Borzuchowska A. Family nurses' opinion on functioning of primary health care system. Probl Hig Epidemiol 2007;88(3):286-93.

30. Mirczak A, Tobiasz-Adamczyk B, Brzyski P, Brzyska M. Rozpoznawanie zjawiska przemocy wobec osób starszych przez pielęgniarki środowiskowe. Probl Pielęg 2011;19(2):202-9.

31. Stefanowicz A, Kulik T, Żołnierczuk-Kieliszek D, Pacian J, Skórzyńska H. Działalność edukacyjna pielęgniarek środowiskowych w zakresie zapobiegania chorobom cywilizacyjnym. Med Ogólna 2010;16(4):496-506.

32. Słońska Z, Borowiec A, Makowska M. Wiedza, postrzeganie własnych kompetencji oraz udzielanie porad z zakresu wybranych behawioralnych czynników ryzyka chorób układu krążenia wśród pielęgniarek podstawowej opieki zdrowotnej. Pol Prz Kardiol 2007;9(1):15-9. 
33. Mojsa W, Owłasiuk A, Marcinowicz L. The knowledge of primary health care nurses of risk factors of cardiovascular disorders. Ann UMCS Sect D 2004;59(Suppl. 14):113-8.

34. Doroszkiewicz H, Bień B. Community nursing care for the elderly during the transformation of the primary health care system. Rocz AM Białyst 2005;50(1):102-6.

35. Owłasiuk A, Marcinowicz L. Rola pielęgniarki rodzinnej w opinii lekarzy podstawowej opieki zdrowotnej (na przykładzie województwa podlaskiego). Pielęg XXI w 2004;1(6):79-82.

36. Leszczyńska M, Krajewska-Kułak E, Łukaszuk C, Sobolewski M, Kędziora-Kornatowska K, Borzuchowska A. Family doctors' opinion on function of primary health care system. Probl Hig Epidemiol 2007;88(3):294-300.

37. Misiak K. Jakość wizyt pielęgniarek środowiskowo-rodzinnych u osób starszych. Gerontol Pol 2004;12(3):139-43.

38. Doroszkiewicz H, Bień B. Quality of teamwork of family doctors and community nurses in primary care for the elderly in two organizational settings - opinions of the family doctors. Adv Med Sci 2007;52(91): 85-8.

39. Strzelecka I, Zieliński A. Rola pielęgniarki środowiskowej w opiece nad pacjentem niepełnosprawnym w podstawowej opiece zdrowotnej. Probl Pielęg 2012;20(1):60-3.
40. Bień B, Doroszkiewicz H, Wojszel BZ. Poziom niesprawności osób starszych a korzystanie z usług medycznych i pozamedycznych w badaniu EUROFAMCARE. Gerontol Pol 2008;16(2):101-10.

41. Zaczyk I, Brzyska M, Stypuła A, Tobiasz-Adamczyk B. Zadania pielęgniarki środowiskowej związane z potrzebami ludzi starszych na podstawie wyników grup fokusowych w ramach projektu europejskiego PROGRES; „Zwiększenie dostępu do środowiskowych form opieki dla osób starszych, mieszkających we własnych gospodarstwach domowych”. Probl Pielęg 2011;19(2):239-43.

42. Mroczek B, Giezek M, Karakiewicz B. Realizacja programów profilaktycznych finansowanych ze środków publicznych. Stan faktyczny i propozycje rozwiązań w pielęgniarstwie środowiskowym/rodzinnym. Fam Med Primary Care Rev 2011;13(1):27-34.

43. Misiak K, Seń M, Felińczak A, Wojewoda B. Jakość profilaktycznych wizyt pielęgniarek środowiskowo-rodzinnych w opinii pacjentów. Ann UMCS Sect D 2005;60(Suppl. 16):456-60.

44. Zdżalik E, Dominiak I, Matusiak M, Kilańska D. Pielęgniarka zdrowia rodziny versus pielęgniarka podstawowej opieki zdrowotnej. Analiza porównawcza kompetencji. Hygeia Public Health 2015;50(92):331-8.

45. Anthony S, Jack S. Qualitative case study methodology in nursing research: an integrative review. J Adv Nurs 2009;65(6):1171-81. 